\title{
THE CONNENCTION BETWEEN GLOBAL INNOVATION INDEX AND ECONOMIC WELL-BEING INDEXES
}

\author{
Szlobodan Vukoszavlyev \\ University of Debrecen, Faculty of Economics and Business, Hungary \\ szlobodan@gmail.com
}

\begin{abstract}
We study the connection of innovation in 126 countries by different well-being indicators and whether there are differences among geographical regions with respect to innovation index score. We approach and define innovation based on Global Innovation Index (GII). The following well-being indicators were emphasized in the research: GDP per capita measured at purchasing power parity, unemployment rate, life expectancy, crude mortality rate, human development index (HDI). Innovation index score was downloaded from the joint publication of 2018 of Cornell University, INSEAD and WIPO, HDI from the website of the UN while we obtained other well-being indicators from the database of the World Bank. Non-parametric hypothesis testing, post-hoc tests and linear regression were used in the study.

We concluded that there are differences among regions/continents based on GII. It is scarcely surprising that North America is the best performer followed by Europe (with significant differences among countries). Central and South Asia scored the next places with high standard deviation. The following regions with significant backwardness include North Africa, West Asia, Latin America, the Caribbean Area, Central and South Asia, and sub-Saharan Africa. Regions lagging behind have lower standard deviation, that is, they are more homogeneous therefore there are no significant differences among countries in the particular region.

In the regression modelling of the Global Innovation Index, it was concluded that GDP per capita, life expectancy and human development index are significant explanatory indicators. In the multivariable regression analysis, HDI remained the only explanatory variable in the final model. It is due to the fact that there was significant multicollinearity among the explanatory variables and the HDI aggregates several non-economic indicators like GII
\end{abstract}

Keywords: innovation, well-being, regression, HDI, global innovation index

(JEL Classification: B41, I31, O31, Q55)

\section{INTRODUCTION}

The growth of the world is an incredibly spectacular process especially when it comes to the evolution of humanity from the prehistory to present days. This process, continuous innovations, developments completely changed the life of humanity. Against this background it is not surprising that the economics of development and innovation are included in the research areas of economics, administration and management sciences. Research, development and innovation (R\&D\&I) are closely related definitions, but it is important to differentiate them. R\&D include 3 categories: basic research, applied research and experimental development. According to the National Research, Development and Innovation Office, 'R\&D are regular creative works aiming at expanding knowledge and knowledge base' (the National Research, Development and Innovation Office, 2018). Regarding life cycle, innovation is made up of 3 sections: invention, innovation and diffusion. Invention is the act of discovering and creating novelties. Innovation is the placement and development of invention into business practice, and diffusion is the widespread adoption of inventions (Schumpeter, 1939). On this basis, it can be concluded that that R\& D is first and foremost involved in invention. 
A detailed definition of innovation first appeared in Schumpeter in 1939, since then the meaning and the underlying definition have changed to a large extent, perhaps due to changes in the macro and micro environment. Today, its interpretation in the Oslo Manual is the most widespread, that is: "innovation is the implementation of

- a new or significantly improved product (good or service), or process

- or a new marketing method

- or a new organizational method

- in business practices, workplace organization or external relations." (Oslo Manual, 2006).

\section{Effects of innovation}

Innovation in any economy, whether natural or controlled, contributes significantly to higher standard of living.

These days, innovation performance is a key factor in maintaining competitiveness and the development of the national economy. In addition, innovation is the key to meeting the global challenges that global population faces (climate change, fossil fuels, sustainability (OECD, 2007).

Several studies demonstrate a strong, positive relationship between innovation and gross domestic product (Goliuk, 2017; Czarnitzki and Toivanen, 2013; OECD, 2007). According to the economic context of the topic, innovation-driven productivity gains are the basis for innovation-driven economic growth, which is expressed primarily in the output of GDP, in gross output (GO) (Gregersen-Johnson, 1997). Gurbiel's (2002) work illustrates the practical side of the process described above, whereby innovation and knowledge transfer are the basis for economic growth and sustainable development; value of R\&D combined with an appropriate transfer process and infrastructure (which is represented in imports and FDI) is a direct cause of productivity growth. These results are qualified by Wang's (2013) empirical research, which found no positive correlation between innovation output and economic growth but may be limited by the fact that Wang only examined patent and trademark statistics over time directly from the Second World War.

Günday et al. (2009) assessed the impact of innovation on corporate performance, and their research suggests that innovation has a positive impact on higher market share, sales volume and exports. These results have been backed by several other empirical studies (Damonpour-Evan, 1984; Despande et al., 1993; Du-Farley, 2001; Canh et al., 2019). Applying basic macro and microeconomic knowledge, changes at the micro level (the impact of innovation on corporate performance) are reflected at national level (though in other indicators).

\section{Measuring $R \& D$ and Innovation}

Primarily, data on $R \& D$ were the base of the quantification and measurement of innovation until the end of the 70's. It is partly due to the interpretation of innovation in that period and the linear approach of innovation process. A more significant change occurred when not only technological novelty on the market, but also the latest categories of innovation (organization, marketing and procedure) and the relatively interpreted novelty (in a new organisation or business practice) became accepted categories (Szunyogh, 2010).

The publication of Oslo Manuals is a milestone in the measurement of innovation, the first edition was published in 1993 and there is an effort to provide a single framework for measuring innovation allowing international comparison. At the same time, a standard questionnaire survey was conducted in the Member States of the European Union, called CIS (Community Innovation Survey) (Sabadie-Kwiatkowski, 2016).

Since innovation has paramount importance in competitiveness, the measurement of innovation is reflected in the Global Competitiveness Report of the World Economic Forum, which includes innovation among the 12 areas used to measure competitiveness (institutions, infrastructure, macroeconomic environment, health and primary education. higher education and vocational training, commodity market efficiency, labour market efficiency, the development of financial markets, availability of technologies, market size, business sophistication, innovation). However technological innovation and knowledge are particularly taken into account in context of innovation to define the Global Innovation Index (Keresztes, 2013). Innovation index of GCI takes the following factors into consideration: innovation capacity, quality of scientific research institutes, corporate $R \& D$ expenditures, university-industry cooperation in $R \& D$, state technology procurement, availability of researchers and engineers, number of patent applications (Schwab, 2017).

The European Union also measures the innovation performance of the Member States and publishes the European Innovation Scoreboard every year. The innovation index is based on 27 indicators looking into four dimensions. The first dimension is the framework conditions for innovation, including human resources, an enticing research system and an innovation-friendly environment. The second dimension is investment, which has two categories: finance and subsidy and corporate investments. The third dimension is innovation, which attempts to measure corporate innovation efforts with three categories: innovators, networking and intellectual property. The fourth dimension is the impact, which intends to quantify the market effects of innovation activity in two categories: effects on employment, effects on sales. After defining the scores for each Member State, it classifies the countries into four innovation performance categories: leading innovators, major innovators, moderate innovators and lagging innovators (European Union, 2018).

Bloomberg innovation index (BII) developed by Bloomberg L.P. is worth mentioning which evaluates the innovation performance of the countries on the basis of six criteria: $R \& D$, production, high-tech enterprises, 
those with secondary qualification, researchers and patents (Jamrisku - Lu, 2018).

The Global Innovation Index (GII) published in a joint publication of the World Intellectual Property Organization (WIPO), Cornell University and INSEAD, uses a more complex approach. The innovation index of 127 countries is calculated on a scale ranging from 0 to 100 using 81 indicators focusing on seven dimensions: institutional system, human resources and research, infrastructure, market development, business development, scientific and technological performance, creative performance (Cornell et. al, 2018). Table 1. shows the composition of the Global Innovation Index.

Table 1. The composition of Global Innovation Index

GLOBAL INNOVATION INDEX (Innovation Efficiency Ratio)

I. Innovation Input - Sub-Index

1. Institutions

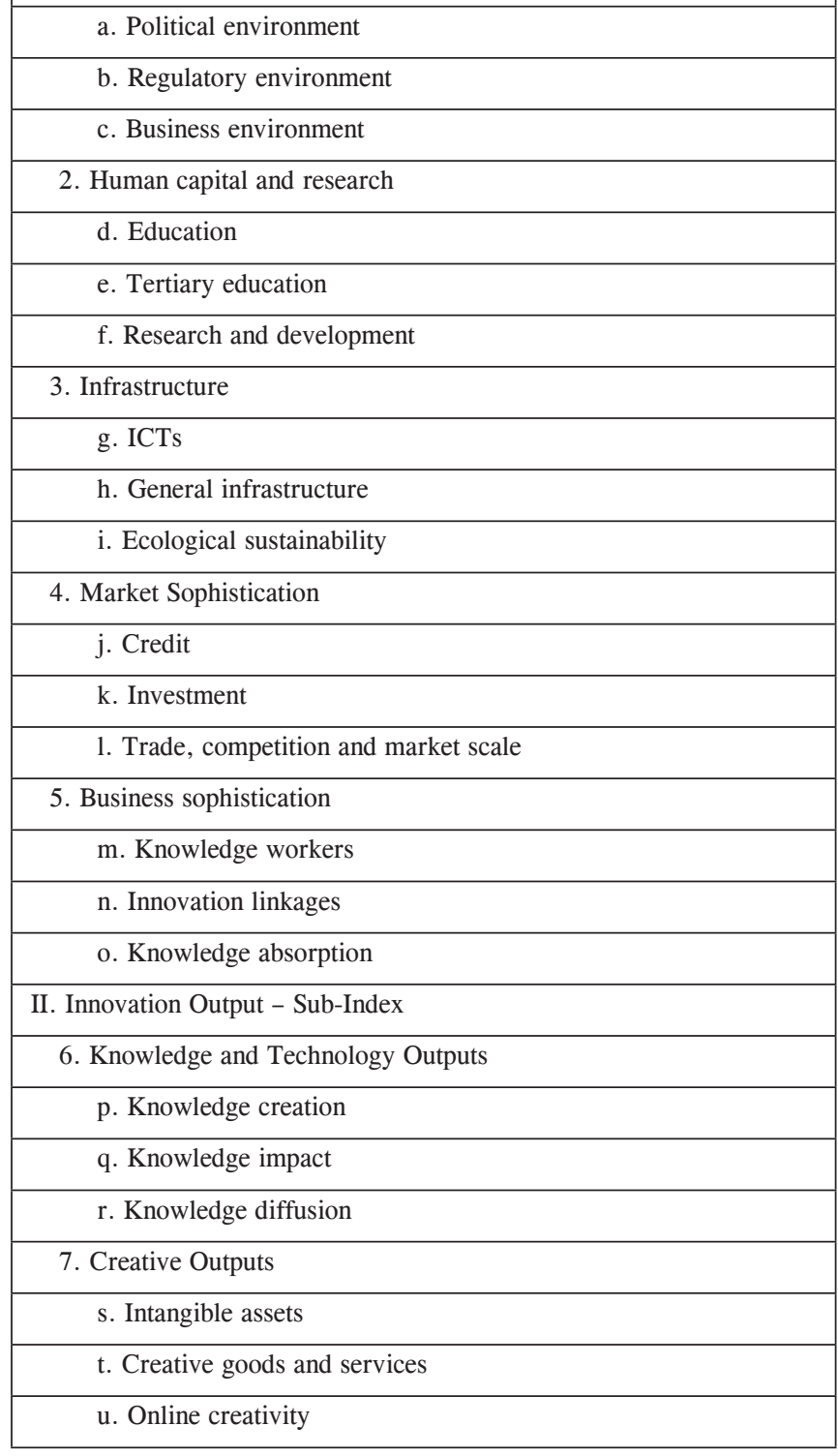

Source: Cornell et al., 2018

\section{Objectives}

The aim of the research is to delve into the relationship between the Global Innovation Index and some important well-being indicators: GDP per capita measured at purchasing power parity in US Dollar, life expectancy, crude mortality rate, unemployment rate, human development index (HDI). In addition, we reveal whether the geographical location (7 regions under the United Nations classification) has an impact on the innovation index.

\section{MATERIALS AND METHODS}

Secondary data are the base of the study. The GII (Global Innovation Index) is from 'The Global Innovation Index 2018: Energizing the World with Innovation' published by Cornell University, INSEAD, and WIPO (Cornell et al., 2018). The following data are from the World Bank database: GDP per capita measured at purchasing power parity in US Dollar, life expectancy, crude mortality rate, unemployment rate (The World Bank, 2018). Data on the Human Development Index were collected from the database of the website of Human Development Reports of the United Nations Development Program (United Nations Development Program, 2018).

In the first step of the research we studied the relationship among our variables with simple Pearson's linear correlation. Afterwards, we continued to study the relationship with linear regression, but it is important to emphasize that we did not intend to reveal a causal relationship with regression, but to get a deeper understanding of the relationship between GII and well-being indicators. The nature of functional relationship between the result variable and the explanatory variable (linear, exponential, logarithmic, inverse) was tested. The condition of the regression error tag was tested with one-sample Kolmogorov-Smirnov test, and the homozygosity was tested with scatter plot. Whether there is a difference between the geographical regions in terms of the innovation index, we used the Kruskal-Wallis test and Dunn's post-hoc test. IMB SPSS 23 was used for the tests.

\section{RESULTS}

\section{Geographical regions and the Global Innovation Index (GII)}

Based on the United Nations classification, seven geographical regions were identified and divided into the following countries: EUR - Europe; NAC - North America; LCN - Latin America and the Caribbean; CSA - Central and South Asia; SEAO - Southeast Asia, East Asia and Oceania; NAWA - North Africa and West Asia; SSF - Sub-Saharan Africa. We studied whether there is a significant difference in GII among these regions. Table 2 . shows the mean innovation index of the regions and how many countries there are in the regions in the sample. 
Table 2. The mean and deviation of GII per region $(n=126)$

\begin{tabular}{|c|c|c|c|}
\hline Region & N & Mean of GII & Deviation \\
\hline NAC & 2 & 56.3950 & 4.82954 \\
\hline EUR & 39 & 46.6659 & 10.04034 \\
\hline SEAO & 15 & 43.8833 & 11.21578 \\
\hline NAWA & 19 & 33.7621 & 8.78049 \\
\hline LCN & 18 & 30.3150 & 4.30719 \\
\hline CSA & 9 & 28.2356 & 4.32029 \\
\hline SSF & 24 & 24.5267 & 4.19485 \\
\hline Sum & 126 & 36.6740 & 12.13085 \\
\hline
\end{tabular}

Source: own calculation

Based on the Kruskal-Wallis non-parametric test it can be concluded that there is a significant difference between the regions $(\mathrm{p}<0.01)$ and the difference between the Dunn posthoc test is significant in the following cases: EUR - NAWA, EUR - LCN, EUR - CSA, EUR - SSF, SEAO - NAWA, SEAO - LCN, SEAO - CSA, SEAO - SSF, NAC - NAWA, NAC - LCN, NAC - CSA, NAC - SSF, NAWA - CSA, NAWA - SSF, CSA - SSF.

Table 3. Correlation of the factors studied $(n=126)$

\begin{tabular}{|c|c|c|c|c|c|c|c|}
\hline & & GII & $\begin{array}{l}\text { GDP/ } \\
\text { capita }\end{array}$ & $\begin{array}{l}\text { Unem- } \\
\text { ployment } \\
\text { rate }\end{array}$ & $\begin{array}{c}\text { Life } \\
\text { expec- } \\
\text { tancy }\end{array}$ & $\begin{array}{l}\text { Mor- } \\
\text { tality } \\
\text { rate }\end{array}$ & HDI \\
\hline \multirow{3}{*}{ GII } & $\mathrm{r}$ & 1 & $.713^{* *}$ & -.089 &, $782 * *$ & .141 & $.842 * *$ \\
\hline & $\mathrm{p}$ & & .000 & .322 & ,000 & .114 & .000 \\
\hline & $\mathrm{N}$ & 126 & 125 & 126 & 126 & 126 & 126 \\
\hline \multirow{3}{*}{$\begin{array}{l}\text { GDP/ } \\
\text { capita }\end{array}$} & $\mathrm{r}$ & $.713 * *$ & 1 & $-.184 *$ &, $655^{* *}$ & $-.191 *$ & $.750 * *$ \\
\hline & $\mathrm{p}$ & .000 & & .040 &, 000 & .033 & .000 \\
\hline & $\mathrm{N}$ & 125 & 125 & 125 & 125 & 125 & 125 \\
\hline \multirow{3}{*}{$\begin{array}{l}\text { Unem- } \\
\text { ploy- } \\
\text { ment } \\
\text { rate }\end{array}$} & $\mathrm{r}$ &,- 089 & $-.184 *$ & 1 &,- 012 & $.208 *$ & .005 \\
\hline & $\mathrm{p}$ & .322 & .040 & & ,891 & .020 & .958 \\
\hline & $\mathrm{N}$ & 126 & 125 & 126 & 126 & 126 & 126 \\
\hline \multirow{3}{*}{$\begin{array}{l}\text { Life } \\
\text { expec- } \\
\text { tancy }\end{array}$} & $\mathrm{r}$ & $.782 * *$ & $.655^{* *}$ & -.012 & 1 & -.129 & $.912 * *$ \\
\hline & $\mathrm{p}$ & .000 & .000 & .891 & & .148 & .000 \\
\hline & $\mathrm{N}$ & 126 & 125 & 126 & 126 & 126 & 126 \\
\hline \multirow{3}{*}{$\begin{array}{l}\text { Mor- } \\
\text { tality } \\
\text { rate }\end{array}$} & $\mathrm{r}$ & .141 & $-.191 *$ & $.208 *$ &,- 129 & 1 & .032 \\
\hline & $\mathrm{p}$ & .114 & .033 & .020 &, 148 & & .722 \\
\hline & $\mathrm{N}$ & 126 & 125 & 126 & 126 & 126 & 126 \\
\hline \multirow{3}{*}{ HDI } & $\mathrm{r}$ & $.842 * *$ & $.750 * *$ & .005 & $.912 * *$ & .032 & 1 \\
\hline & $\mathrm{p}$ & .000 & .000 & .958 & .000 & .722 & \\
\hline & $\mathrm{N}$ & 126 & 125 & 126 & 126 & 126 & 126 \\
\hline
\end{tabular}

\section{Revealing the functional relationship between GII and explanatory variables}

In the first step of regression modelling, we tested whether there is a linear relationship between our explanatory variables and the innovation index, where no linear relationship was found, exponential, logarithmic and inverse function-like relationships were also studied. In terms of GDP per capita it was concluded that it has a linear relationship with the GII, the determination coefficient is $\mathrm{r} 2$ $=0.508$, which means that $50.8 \%$ of the global deviation of the global innovation index can be explained by GDP per capita. Modelling can be considered accurate based on the standard error of estimation (SEE $=8.47$ ). Furthermore, the F-test of variance analysis (ANOVA) confirms the existence of the relationship ( $\mathrm{p}<0.01$ ) between the GDP per capita and the GII, the significance of variable defining the slope is lower than $5 \%$ based on the t-probe, therefore GDP per capita affects GII. Based on OLS estimation, we get the following linear equation:

$$
\text { (1) GII }=27.567+0.000376 * \text { GDP per capita }
$$

It may be considerable that the coefficient of GDP per capita as an explanatory variable is very low; it is due to the fact that GII is a variable measuring at a scale ranging from 0 to 100 while GDP per capita is a metric random variable of 10 thousand.

Regarding the connection between the unemployment rate as an explanatory variable and the GII as a result variable, there is neither a linear nor any other function-like relationship, but the linear relationship between life expectancy and GII can be verified. The determination coefficient in this case is $\mathrm{r} 2=$ 0.612 , the model's accuracy is SEE $=7.587$. The F-test of the variance analysis also confirms the existence of the relationship ( $p<0.01$ ) between life expectancy and GII, and the significance of the slope variable is less than 5\% based on the t-test, thus life expectancy affects GII by the following equation:

$$
\text { (2) GII }=-61,069+1,323 * \text { life expectancy }
$$

Interpreting the equation, it can be concluded that there is a positive, linear, function-like relationship between life expectancy and GII. Of course, the innovation index cannot be explained by life expectancy, but if we rearrange the equation, we find the following connection:

$$
\text { (3) life expectancy }=1 / 1.323 * \text { GII }+61.068 / 1.323 \text {, }
$$

that is, if GII increases by one unit, life expectancy increases by 0,756 years,

There is also no functional relationship between the mortality rate as an explanatory variable and the global innovation index as a result variable. The linear relationship between HDI and GII is significant with the determination coefficient of $\mathrm{r}^{2}=0.708$. The model meets all the additional requirements and the relationship can be described by the following equation:

$$
\text { (4) GII }=-16.417+70.582 * \text { HDI }
$$

Overall, the linear function-like relationship was the most appropriate for all the acceptable models. Table 4 shows the characteristics of each linear model. 
Table 4. Characteristics of the linear models $(n=126)$

\begin{tabular}{|c|c|c|c|c|c|c|}
\hline & $\begin{array}{l}\text { Coeffi- } \\
\text { cient }\end{array}$ & $r^{2}$ & corr. $\mathrm{r}^{2}$ & $\begin{array}{l}\mathrm{F} \text {-test } \\
\text { sig. }\end{array}$ & $\begin{array}{c}\text { t-test on } \\
\text { dep. variable } \\
\text { value/sig. } \\
\text { lev. }\end{array}$ & $\begin{array}{c}\text { Decision } \\
\text { on the } \\
\text { model }\end{array}$ \\
\hline $\begin{array}{l}\text { GDP/ } \\
\text { capita }\end{array}$ & 0.000376 & 0.508 & 0.504 & 0.000 & $\begin{array}{c}11.263 / \\
0.000\end{array}$ & Accepted \\
\hline $\begin{array}{l}\text { Unem- } \\
\text { ployment } \\
\text { rate }\end{array}$ & -0.192 & 0.008 & 0.000 & 0.322 & $\begin{array}{c}-0.9914 / \\
0.322\end{array}$ & Rejected \\
\hline $\begin{array}{l}\text { Life ex- } \\
\text { pectancy }\end{array}$ & 1.323 & 0.612 & 0.609 & 0.000 & $\begin{array}{c}13.983 / \\
0.000\end{array}$ & Accepted \\
\hline $\begin{array}{l}\text { Mortality } \\
\text { rate }\end{array}$ & 0.601 & 0.020 & 0.012 & 0.114 & $1.59 / 0.114$ & Rejected \\
\hline HDI & 70.582 & 0.708 & 0.706 & 0.000 & $\begin{array}{c}17.345 / \\
0.000\end{array}$ & Accepted \\
\hline
\end{tabular}

Source: own calculation

\section{Multivariate regression modelling of GII}

In the first step of GII's multivariate regression modelling, the previously adopted explanatory variables (GDP per capita, life expectancy, HDI) were included in the study. The first multivariate model induced some problems: on one hand, the coefficient of life expectancy, which had a significant explanatory power in the previously univariate relationship, was no longer significant in the multivariate model. Although the estimation errors had normal distribution, the standard deviation of the remaining factors in the model is far from constant, heteroskedasticity persisted, which distorted parameter estimates and doubted the results of the $t$ and F-tests (Hunyadi - Vita, 2005; Ramanathan, 2003). To solve this problem we logarithmized (ten-logarithm of the result variable (GII)), our result variable (GII), although logarithmization defects the interpretation of the results, it is not a problem for us, since the purpose of multivariate regression testing is the estimation of GII (Sajtos - Mitev, 2007; Koop, 2007; Maddala, 2004). Afterwards, the multivariate regression was run again, but with the logarithmic global innovation index. In this case, the problem of heteroscedasticity disappeared, the coefficient of life expectancy and GDP per capita no longer had a significant explanatory power in the model, so life expectancy was removed in the first step. In this model, where we had only two explanatory variables, we still had no significant explanatory power for GDP per capita. There may be several reasons for this: on one hand, GDP per capita is a variable measured at a significantly higher interval, on the other hand there is significant multicollinearity in the model, as GDP per capita and HDI are strong $(\mathrm{r}=0.75)$ and significant correlation ( $\mathrm{p}<0.01)$ exists. Therefore, we decided to remove GDP per capita from the model, so we returned to univariate regression, where our model was no longer affected by heteroskedasticity. The resulting final model is:

(5) $\lg$ GII $=2.048+1.995 *$ HDI
With the model, we are able to explain $78 \%$ of the total variance of the global innovation index $(\mathrm{r} 2=0.780$, corrected r2 $=0.778)$. In the model, both the coefficient of constant and HDI had significant explanatory power. The standard errors of the estimation have normal distribution, which was tested with the Kolmogorov-Smirnov test $(p=0.200>0.05)$, and the standard deviation of the remaining factors can be considered constant based on scatterplot. Presumably, HDI remained in the final model, because there is a strong correlation between the explanatory variables, almost without exception and the effectiveness of the model is defected by multicollinearity and it was HDI that had the strongest correlation with GII. Although there is an assumption that GDP per capita would have been the indicator that explains the GII to the greatest extent, yet HDI had the greatest explanatory power. It is backed by by the composition of HDI and GII, because GII aggravates not only economic factors, HDI also considers other factors besides economic factors, which may have an underlying relationship with the innovation performance of a national economy.

\section{CONCLUSION}

As a conclusion, there are differences among the geographical regions in innovation performance of national economies based on the global innovation index. North American countries (USA and Canada) are in the top (56.4), but the European region also has a relatively high mean score (46.67), although it must be emphasized that there is a significant deviation among European countries (10.04) where Eastern Europe lag behind to a greater extent, but the two regions (NAC and EUR) do not differ significantly. Southeast Asia also represents a higher level of innovation performance (43.8), but there is also a significant deviation (11.22) and innovation performance among countries. There is no significant difference between this region and Europe. As a consequence, 3 regions (NAC, EUR, SEAO) have leading power in innovation.

Larger (significant) backwardness can be seen regarding North Africa and West Asia (33.76), with less and less deviation (8.78), followed by Latin America and the Caribbean (GII mean $=30.31$, deviation $=4.31$ ) then Central and South Asia (GII mean $=28.24$, deviation $=4.32$ ), while Sub-Saharan Africa $($ GII mean $=24.53$, standard deviation $=4.19)$, has significant backwardness.

Our research highlighted that there is a correlation between the innovation performance of a national economy and GDP per capita at purchasing power parity, life expectancy and human development index (HDI). HDI had the strongest link with the innovation index (but the correlation coefficient with the innovation index is higher than 0.7 in all the three cases), and the multivariate regression analysis showed that HDI itself is the most suitable to estimate the innovation index (r2). $=0.78$ ). Consequently, due to the fact that HDI aggregates three factors (GNI index, life expectancy index), these factors may also have a strong relationship with the innovation performance of a national economy. The research proved that the impact of education, the health of population and income are also reflected in innovation. 


\section{REFERENCES}

Canh N. T., Lien N. T., Thu P. A., Khoung N. V. (2019): The Impact of Innovation ont he Firm Performance and Corporate Social Responsibility of Vietnamese Manufacturing Firms. Sustainability, 2019:11.

Cornell University, INSEAD and WIPO (2018): The Global Innovation Index 2018: Energizing The World with Innovation. Ithaca, Fontainebleau and Geneva.

Czarnitzki D. - Toivanen O. (2013): Innovation Polity and Economic Growth. European Economy: Economic Papers , 482.

Damanpour F., Evan, W. M. (1984): Organisational innovation and performance: theproblem of "organisational lag". Administrative Science Quarterly, 29(3), 392-409.

Deshpande R., Farley J. U., Webster Jr. F. (1993): Corporate culture, customerorientation, and innovativeness in Japanese Drms: a quadrate analysis. Journalof Marketing, 57, 23-27.

Du R., Farley J., (2001): Research on technological innovation as seen through theChinese looking glass. Journal of Enterprising Culture, 9 (1), 53-89.

European Union (2018): European Innovation Scoreboard 2018. Publication Office of the European Union, Luxembourg. Available at: https://ec.europa.eu/docsroom/documents/33147

Goliuk V. (2017): Impact of Innovations on DGP Dynamics. वास्यास

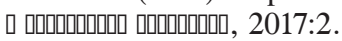

Gregersen B. - Johnson B. (1997): Learning Economics, Innovation Systems and European Integration. Regional Studies, 31(5), 479-490.

Gurbiel R. (2002): Impact of Innovation and Technology Transfer on Economic Growth: The Central and Eastern Europe Experience. Warsaw. Available at: https://www.eadi.org/typo3/fileadmin/WG Documents/Reg_WG/gurbiel.pdf

Günday G., Ulusoy G. Kilic K., Alpkan L. (2019): Effects of innovation types on firm performance. International Journal Production Economics, 133. 662-676.

Hunyadi L. ᄀ- Vita L. (2005): Statisztika közgazdászoknak. Központi Statisztikai Hivatal, Budapest.

Jamrisko M.- Lu W. (2018) The U.S. Drops Out of the Top 10 in Innovation Ranking. Bloombert L.P. Available at: https://www. bloomberg.com/news/articles/2018-01-22/south-korea-tops-globalinnovation-ranking-again-as-u-s-falls

Keresztes G. (2010): Az innovációs tevékenység mérésének lehetőségei. Ekonomicke studie - teória a prax. ISBN 978-80971251-2-7, 323-336.

Koop G. (2007): Közgazdasági adatok elemzése. Akadémiai Kiadó, Budapest.

Maddala G. S. (2004): Bevezetés az ökonometriába. Universitas, Budapest.

NKFI (2018): Fogalomtár. Letöltve: http://nkfih.gov.hu/szakpolitikastrategia/fogalomtar/fogalomtar

OECD (2006): Oslo Manual (3rd ed.), Available at: http://www.oecd.org/sti/inno/ 